\title{
THE EFFECT OF ONLINE LEARNING SYSTEM DURING THE COVID-19 PANDEMIC ON STUDENTS' LEARNING MOTIVATION AND INTEREST IN LEARNING
}

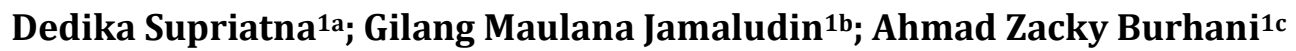 \\ 1University of Majalengka, West Java, Indonesia \\ agmaulana231@gmail.com, bdikded151@gmail.com
}

\begin{abstract}
The background of the study is the issue showing that student's learning interest and motivation of Islamic religious education subject in Junior High School (SMP) Plus Hafadata, Argapura subdistrict which is still low in common, especially during the Covid19 Pandemic. The study objective is to find how is the online learning system in SMP Plus Hafadata Yusuf. How it is the student's learning motivation in SMP Plus Hafadata Yusuf, the student's learning interest in SMP Plus Hafadata Yusuf, and the influence of online learning system toward the student's learning interest and motivation during the Covid-19 pandemic in SMP Plus Hafadata Yusuf. Generally, the study is empirical study by applying the quantitative research method of experiment research type. The data collection technique using conducting observation, interviews, questionnaires or forms, and documentation. The online learning system influence is quite good toward student's learning interest and motivation on Islamic religious education subject of class VII in SMP Plus Hafadata Yusuf. This shows that implementing the online learning system can influence the student's learning interest and motivation compared to the one who did not use online learning system.
\end{abstract}

Keywords: online, pandemic, motivation, learning, interest

\section{INTRODUCTION}

The educational institution is regarded as an institution creating a developed and advanced youth generation where they can survive in the real-life through education. With the assistance of education, every individual wants to move forward and finishes the education, the individual may earn a decent job and comfortable life. The definition of education itself is explained completely in the constitution number 20 of 2003 on National Education which states that "Education is a conscious and planned effort to create a learning atmosphere and learning process in order the student can develop 
their potential actively to have spiritual strength, self-control, society, nation, and state". This corresponds to Allah's command in the chapter of Al-Baqara verse 45 , it says:

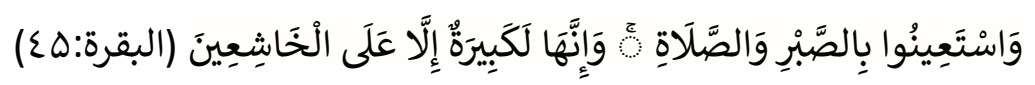

It means: "And seek help through patience and prayer, and indeed, it is difficult except for the humbly submissive (to Allah)".

Therefore, in dealing with the education field, it is required to strive and earnestly to achieve a purpose where the education objective is more like humanizing humans through various strategies, creativities, or innovations to achieve the expected education. In the education process itself, there is a very noble objective whereby the teacher instills values to the pupil to achieve the educational objectives. Allah the Almighty will ease the way to the heaven for the servant who always seeks knowledge. As the following hadith narrated by Abu Abu Hurairah Ra, the Messenger of Allah says:

$$
\text { مَنْ سَلَكَ طَرِيقًا يَلْتَمِسُ فِيِه عِلْمًا سَهَّلَ اللَّهُ لَهُ بِهِ طَرِيقًا إِلَى الْجَنَّةِ (مسلم) }
$$

It means: "Whoever takes the path to seek knowledge, Allah will ease the way to heaven for him". (HR. Muslim)

Through the knowledge possessed, Allah will ease them to conduct the good deeds. Meanwhile, good deeds are instrument or medium for a servant of Allah to enter the heaven. "Education is an essential aspect in life, it is an asset to traverse the times successively. Becoming a developed nation is naturally every nation's expectation, it is influenced by education. Education is so much important, thus, the development of education influences the country's progress. And by education, it will crease the good and qualified human resources" Gm Jamaludin, A Rosidah, E Nurbaiti, (2020:132).

The rapid development of information technology in today's globalization era is inevitable in its influence on education. The Global demands that education must always and constantly adjust to technological development on the effort of improving education quality, especially in adjusting its usage for education, particularly in the learning process, the 
development of industrial revolution 4.0 era has given significant influence on learning that must adjust and utilize technology in the era Ghiffar, et.al. (2018). The changes in the demand make education needs innovation and creativity in its learning process. At the beginning of 2020, the world was shocked by the outbreak of the coronavirus from China Budiyanti, (2020). Indonesia is affected and it becomes a severe problem in the current learning process. Because of the outbreak of coronavirus (Covid-19), there is a policy to dismiss all the educational institution as the effort to contain coronavirus infection Arifudin, (2020). In the Circular of Ministry of Education and Culture Republic Indonesia Number 4 in 2020 on Educational Policy Implementation of Corona Virus Disease (Covid-19) Emergency Period in item $2 \mathrm{a}$, it was mentioned that the learning process from the home through online learning/distance learning is conducted to give a meaningful experience for the student Pusdiklat Kemendikbud RI, (2020).

One of the solutions that can be conducted in the learning process is that distance learning utilizes the existing technology. Currently in Indonesia, the educational institution has applied online learning activity. Online learning is indirect learning without having face to face using internet technology, so that, it is connected from a distance. According to Michael, (2013:27) "Elearning is an arranger learning with the purpose to use an electronic system or also computer, so it can support a learning process". From the explanation, according to Kemenristekdikti team, (2017), it says that online learning is the learning "within a network" as the translation of 'online' term which means connected into the computer network.

The success of an educational process is really influenced by the continuing learning because it is the core of the educational process; in learning, student's motivation to participate learning is a very important aspect. Student's learning interests and motivation are very needed to achieve the learning objective because it is as the influencing factor to the success in learning. According to Djalil, (2013) said that factors influences 
student's in learning is the existence of internal and external factors. Internal factors such as health, intelligence, interest, motivation, and their way of study. While external factors such as family, school, society, and also the environment.

The first factor is the low motivation to study, giving motivation means the effort to provide situation and condition, so the children will, want to do it. Children with high intelligence, maybe fail in the lesson because of the lack of motivation. The best outcome is achieved with strong motivation. The failing kid is not necessarily to be blamed. It is probably the teacher has not succeeded in evoking motivation to the pupil's activity S. Nasution, (2000). Hence, the pupil will be motivated in studying if the environment can give the stimulus, so that, the pupil are interested to study. The comprehending and utilizing the class atmosphere well by the pupil is expected can support its success in learning Elida Prayino, (1989). In this case, it is clear that learning also very affecting the student's learning motivation; and the teacher's role is very important to evoke and give motivation to the pupil. Thus, there is a difference in the learning system at the school changes to the family environment. As for the student's characteristics who are motivated, i.e. diligent, resilient in facing hardship, showing interest in various kinds of problems, prefer to work alone, easily to be bored with an assignment, able to defend the argument, fondness to seek and solve problems.

The second factor influencing the low rate of success in studying is learning interest. The learning interest is something from within the student itself influenced by the intention to study. According to Sardiman, (2008: 76) "intention can be interpreted as a condition occurred if a person sees temporary characteristics or meanings that are related to their intentions or needs. The intention existed in a person will describe the activity to achieve the purpose". Learning interest can be said as important in learning activity because it has a great influence on the passion to study. A student who has an interest in a certain subject surely will study the subject earnestly such as 
diligent in learning, enjoy to follow the subject even though they find difficulties in the study. Conversely, if the student did not have an interest in a certain subject, thus it will be difficult for the student to learn well. Naturally, this will influence the student's interest in the study.

Based on the data obtained from the headmaster of SMP Plus Hafadata Yusuf Argapura sub-district on 06 July 2020, the learning-teaching activity has not been entirely yet implementing online learning, the medium used still uses photocopy sheet material, the brief explanation makes the student difficult to understand the lesson, and also online learning devices have not been prepared yet. Many students do not have an android mobile phone or smartphone, the unpleasant environment makes the student cannot concentrate on learning, so it makes the student's learning motivation and interest become low. Starting in July, there is a plan to apply online learning, starting on august, it has been implemented online learning in the school.

\section{THEORETICAL FRAMEWORK}

1. Online Learning System

Online learning is "within a network" learning as an interpretation of an online term which means it is connected into the computer network Kemenristekdikti Team (2017). "Online learning is the online learning strategy or is conducted within the network" Mustofa, et.al. (2019:11). Online learning is the strategy in learning that is pleasant for the participants because they can listen to it through an android handphone, laptop, or computer, not just from books Sobron A.N, et.al. (2019). Nurhayati, (2020) states that E-learning for the first time was introduced by Illinois University in Urbana-Champaign using a computer-assisted instruction system and a computer named PLATO.

Benny A. Pribadi, (2017:203) said that "learning activity through Elearning can help students to achieve ability or competence required in effective and efficient way. The E-learning user can save time and perform 
the learning process with more time duration". According to Michael, (2013:27) says that "E-learning is the learning arranged for the purpose to use an electronic system or also computer, so that, it is able to support a learning process". According to Ardiansyah, (2013) in Setiawan, (2020) Elearning is a learning system used as a teaching-learning process carried out without face to face directly between the teacher and the students.

\section{Learning Motivation}

According to Sardiman, (2014:75) explained that "learning motivation is the psychic factor that is non-intellectual. The unique role is in growing the passion, enjoying and being enthusiasm to study. Later on, Hamzah B. Uno, (2010:23) mentioned that "the essence of learning motivation is internal and external encouragement to the students who are studying to make changes in behavior, commonly with some indicators or supporting elements. Based on the explanation above, it can be concluded that learning motivation is the encouragement inside a person that can be influenced by an internal or external factor, that will encourage a person to conduct a learning activity to achieve a certain objective. This learning motivation will direct the person during studying activities.

\section{Learning Interest}

Interest is one of the main factors to achieve success in every field, either in the study, work, hobby, or any other activities. This is because there is increasing interest within a person that will create attention to perform something diligently and in the long term, more concentrating, easy to remember, and not easily to get bored. Interest is a psychological factor that everybody has. Thus, interest in something/certain activity that can be owned by everybody. If a person is interested in something, an interest will emerge. 
According to Sardiman, (2014:76) interest can be defined as a condition occurred if a person sees the temporary characteristics or meanings that are associated with his intentions or needs. The interest in a person will describe the activity to achieve the purpose. Crow and Crow in Djaali, (2013) say that interest is related to the force of motion to deal with or try with someone, object, activity, experience that is stimulated by its activity. Learning intention is one of the forms of one's activeness that is encouraged to perform a set of physical or mental activity to obtain a change in behavior as the result of individual experience in the environment related to cognitive, affective, and psychomotor.

The covid-19 pandemic condition requires all students to study at home using an online learning medium prepared by the school. The learning benefit during the current Covid-19 pandemic is that the student has much spare time at home, save transportation costs, and decrease in traffic jams (Purwanto et al. 2020). Some shortcomings in online learning or at home is the students often feel bored, this condition is caused by the student is alone or doing a monotone activity at home, besides boring on online learning also decreasing student's learning motivation, increasing electricity and internet cost (Nurhasanah, 2016). The result is caused by learning at home or online decreases the student's learning interest and motivation as an impact of the continuing bored student condition at home (Siagian, 2015).

During the pandemic period, the learning process is expected to continue as planned, for the learning to keep on going, so it makes policy to study at home. The students have problems when the teacher gave the assignment. During making the assignment, they seem to play a lot. The game and such kind of it mostly disrupts the student, so that, the many assignments were completed or they did it (Setyorini, 2020). One of the schools that is succeeded in online learning is Integrated Islamic Elementary School (SD IT) Rabi Radhiyya Curup. The evaluation result conducted shows the learning process run as planned and the target. Some of the learning activities on 
building characters are tahfidz, tahsin, memorizing hadith and prayer, and other activities also run well, so does the assignment given by the teacher to be done at home as planned (Sutarto et al. 2020). The researchers have already conducted a study on learning strategy. Most of the researchers are studying on face to face or offline learning strategies in normal conditions. The result of their research shows that there is an influence on student's learning outcomes with learning strategy (Hattie, 2016; Nasution, 2018; Solihatin \& Syahrial, 2019).

\section{METHOD}

The research method used in this study is the quantitative approach. According to Sugiyono, (2019:16) he says that the quantitative research method is because the data research is in the form of numbers and the analysis uses statistics. The design of the study uses Quasi-Experimental Design, the research design used is Nonequivalent Control Group Design. Whereas the experiment or control group is not selected randomly. The experiment and control group are conducted with the initial test. The two groups get different treatment, whereas the experiment group uses online learning, and the control group uses offline learning and ends with a final test for each group.

Table 1

Research Design

\begin{tabular}{|c|c|c|c|}
\hline $\mathbf{E}$ & $\mathbf{O}_{1}$ & $\mathbf{X}_{1}$ & $\mathbf{O}_{2}$ \\
\hline $\mathbf{K}$ & $\mathbf{O}_{3}$ & $\mathbf{X}_{2}$ & $\mathbf{O}_{4}$ \\
\hline
\end{tabular}

Remark:

E: Experiment Class

K: Control Class

01: Initial Test (before treatment) in the experiment group

02: Final test (after treatment) on the experiment group 
03: Initial test (before treatment) on the control group

04: Initial test (after treatment) on the control group

X1: Online learning implementation

X2: Offline learning implementation

The population in this research are class VII students in SMP Hafadata Yusuf Argapura sub-district consisted of 29 students. The sample used in the study is a saturated sample, whereas all of the populations were used as a sample. The sample used in the study is the entire students in class VII which are divided into two groups, those are experiment class group, and control class group.

\section{RESULT DAN DISCUSSION}

T-test aims to find out whether there is a significant difference between the result of the experiment class and the control class. Thus, the research uses the independent samples T-test model, with the following criteria:

If the Prob value/Significance/P-value $<\alpha$ so $\mathrm{H} 0$ is rejected

If the Prob value/Significance/P-value $\geq \alpha$ so $\mathrm{HO}$ is received

Table 2

Independent Sampel Test

\begin{tabular}{|c|c|c|c|c|c|c|c|c|c|c|}
\hline \multicolumn{11}{|c|}{ Independent Samples Test } \\
\hline & & \multicolumn{2}{|c|}{$\begin{array}{l}\text { Levene's Test for Equality of } \\
\text { Variances }\end{array}$} & \multicolumn{7}{|c|}{ t-test for Equality of Means } \\
\hline & & \multirow[b]{2}{*}{$\mathrm{F}$} & \multirow[b]{2}{*}{ Sig. } & \multirow[b]{2}{*}{$t$} & \multirow[b]{2}{*}{ df } & \multirow[b]{2}{*}{ Sig. (2-tailed) } & \multirow{2}{*}{$\begin{array}{l}\text { Mean } \\
\text { Difference }\end{array}$} & \multirow{2}{*}{$\begin{array}{l}\text { Std. Error } \\
\text { Difference }\end{array}$} & \multicolumn{2}{|c|}{$\begin{array}{l}95 \% \text { Confidence Interval of the } \\
\text { Difference }\end{array}$} \\
\hline & & & & & & & & & Lower & Upper \\
\hline \multirow[t]{2}{*}{ tes motivasi } & $\begin{array}{l}\text { Equal variances } \\
\text { assumed }\end{array}$ & .545 & .467 & 9.464 & 27 & .000 & 25.095 & 2.652 & 19.654 & 30.536 \\
\hline & $\begin{array}{l}\text { Equal variances not } \\
\text { assumed }\end{array}$ & & & 9.522 & 26.732 & .000 & 25.095 & 2.636 & 19.685 & 30.505 \\
\hline
\end{tabular}

Based on the test result on the above table, it is obtained $\mathrm{F}$ value, assumes that the both same variants are 0.545 with $t$ value $=9.464$ with independent degree (df) of $=n_{1}+n_{2}-2=(14+15-2=27) \cdot \alpha=0.05$ it is 
obtained Sig. 0.000. Because of Sig. $0.000<0.05$, thus H0 is rejected or in the other words, Ha is received. It means there is a significant difference between learning motivation between students in the experiment class, which was given online learning treatment and the control class which did not use online learning. This shows that using an online learning system can influence the student's learning motivation compared to the class which did not use online learning.

Table 3

\begin{tabular}{|c|c|c|c|c|c|c|c|c|c|c|}
\hline \multicolumn{11}{|c|}{$\begin{array}{l}\text { Independent Sampel Test } \\
\text { Independent Samples Test }\end{array}$} \\
\hline & & \multicolumn{2}{|c|}{$\begin{array}{l}\text { Levene's Test for Equality of } \\
\text { Variances }\end{array}$} & \multicolumn{7}{|c|}{ t-test for Equality of Means } \\
\hline & & \multirow[b]{2}{*}{$\mathrm{F}$} & \multirow[b]{2}{*}{ Sig. } & \multirow[b]{2}{*}{$t$} & \multirow[b]{2}{*}{ df } & \multirow[b]{2}{*}{ Sig. (2-tailed) } & \multirow{2}{*}{$\begin{array}{l}\text { Mean } \\
\text { Difference }\end{array}$} & \multirow{2}{*}{$\begin{array}{l}\text { Std. Error } \\
\text { Difference }\end{array}$} & \multicolumn{2}{|c|}{$\begin{array}{l}95 \% \text { Confidence Interval of the } \\
\text { Difference }\end{array}$} \\
\hline & & & & & & & & & Lower & Upper \\
\hline \multirow[t]{2}{*}{ tes minat } & $\begin{array}{l}\text { Equal variances } \\
\text { assumed }\end{array}$ & 3.428 & .075 & 10.244 & 27 & .000 & 28.143 & 2.747 & 22.506 & 33.780 \\
\hline & $\begin{array}{l}\text { Equal variances not } \\
\text { assumed }\end{array}$ & & & 10.346 & 25.869 & .000 & 28.143 & 2.720 & 22.550 & 33.736 \\
\hline
\end{tabular}

Based on the test result on above table, it is obtained $\mathrm{F}$ value assuming that the both same variants are 3.428 with $\mathrm{t}$-value of $=10.244$ with independent degree (df) of $=n_{1}+n_{2}-2=(14+15-2=27) \cdot \alpha=0.05$ it is obtained Sig. 0.000. Because of Sig. $0.000<0.05$, thus $\mathrm{HO}$ is rejected or in other word Ha is received, it means there is a significant difference between students' learning interest in experiment class given with online learning treatment and control class which did not use online learning. This shows that the online learning system can influence a student's learning interest compared to the class that did not use online learning.

From the set activities of the research, the most final stage of research is the hypothesis test which aims to prove the hypothesis proposed by the writer. i.e.: working hypothesis (Ha). The working hypothesis states that there is a relation between variable $\mathrm{x}$ and $\mathrm{y}$, or there is a difference between the two groups. Zero hypothesis (H0) or statistics hypothesis because it can be used in the statistical research which is tested statistically. The result of 
hypothesis pre-test and post-test uses t-test can be seen in the following table:

Table 4

Data result in T-test of Pre-test and Post-test

Experiment and Control Class

\begin{tabular}{|l|l|l|}
\hline \multicolumn{1}{|c|}{ Data } & \multicolumn{1}{|c|}{ T count } & T table \\
\hline Pretest Motivation & 0.525 & 1.708 \\
\hline Posttest Motivation & 8.706 & 1.708 \\
\hline Pretest Interest & 1.285 & 1.708 \\
\hline Posttest Interest & 10.012 & 1.708 \\
\hline
\end{tabular}

Based on the above table, it can be concluded that variable $\mathrm{X}$, there is a significant influence on variable $\mathrm{Y}_{1}$ and $\mathrm{Y}_{2}$. From the test, it is proven that "there is influence on online learning system toward student's learning motivation and interest in class VII during the Covid-19 Pandemic on Islamic religious education subject in SMP Plus Hafadata Yusuf Argapura subdistrict".

\section{CONCLUSION}

From the research and the data process, the influence of online learning system toward student's learning interest and motivation on Islamic religious education subject of class VII in SMP Plus Hafadata Yusuf Argapura subdistrict 2020/2021 academic year can be concluded by the writer as follows:

The influence of online learning system during the Covid-19 pandemic toward student's interest and motivation of class VII in SMP Plus Hafadata Yusuf, the result of pre-test before it is given treatment on experiment group, the average score in learning motivation of experiment class group is 62.86 and learning interest is 62.86, control group with the average score in learning motivation is 61.47 and learning interest is 59.33 . While the post- 
test result after being given treatment is obtained $\mathrm{F}$ value assuming that the both same variant is 0.545 with $t$-value of $=9,464$ with the independence degree (df) of $=n_{1}+n_{2}-2=(14+15-2=27) . \alpha=0.05$ it is obtained Sig. 0.000. Because of Sig. $0.000<0.05$, thus H0 is rejected or in the other words, $\mathrm{Ha}$ is received. It is obtained $\mathrm{F}$ value assuming that the both same variant is 3.428 with $\mathrm{t}$-value of $=10,244$ with the independent degree $(\mathrm{df})=\mathrm{n}_{1}+\mathrm{n}_{2}-2$ $=(14+15-2=27) \cdot \alpha=0.05$ it is obtained Sig. 0.000 . Because of Sig. $0.000<$ 0.05 , therefore, $\mathrm{H} 0$ is rejected or in other word Ha is received, it means that there is significant difference. This shows that implementing an online learning system can influence student's learning motivation and interest compared to the class which did not implement online learning.

\section{BIBLIOGRAPHY}

A.M, Sardiman. 2000. Interaksi dan Motivasi Belajar Mengajar. Jakarta: PT RajaGrafindo Persada.

Allen, Michael. 2013. Michael Allen's Guide to E-learning. Canada : John Wiley \& Sons.

Al-Qur'an. 2006. al-Qur'an dan Terjemahannya, Bandung: CV Penerbit Diponegoro.

Arifudin, Opan. 2020. Pandemi Corona dan Dampak Terhadap Dunia Pendidikan. Diakses 17 Maret 2020.

Arikunto, Suharsimi. 2014. Prosedur Penelitian Suatu Pendekatan Praktik. Jakarta: PT Rineka Cipta.

Benny, A. Pribadi. 2017. Media \& Teknologi Dalam Pembelajaran.Jakarta Kencana.

Budiyanti, Eka. 2020. Dampak Virus Corona Terhadap Sektor Perdagangan dan Pariwisata Indonesia. Info Singkat, Vol.XII, No.4/II/Puslit/Februari/2020.

Dimyati \& Mudjiono. 2009. Belajar dan Pembelajaran. Jakarta: Rineka Cipta. 
Hamzah B. Uno. 2010. Teori Motivasi dan Pengukurannya. Jakarta: Bumi Aksara.

Ghiffar, Muhammad Alfarizqi Nizamuddin, dkk. 2018. Model Pembelajaran Berbasis Blended Learning Dalam Meningkatkan Critical Thinking Skills Untuk Menghadapi Era Revolusi Industri 4.0. Prosiding Seminar Nasional Pendidikan, STKIP Andi Matappa Pangkep.

GM Jamaludin, Ani Rosidah, Endah Nurbaiti. 2020. Meningkatkan Kemampuan Berfikir Kritis Dan Hasil Belajar Siswa Dengan Penggunaan Media Lapbook. Jurnal Basicedu.

Hattie, J. A., \& Donoghue, G. M. (2016). Learning Strategies: A synthesis and conceptual model. Npj Science of Learning, 1(1), 1-13.

Nasution, W. N. (2018). Pengaruh Strategi Pembelajaran dan Motivasi Belajar terhadap Hasil Belajar Pendidikan Agama Jslam (PAI). Repository.Uinsu.Ac.Id.

Nurhayati. 2020. Metode Pembelajaran Daring/E-learning yang efektif. Skripsi. Jurusan Ilmu Pendidikan Psikologi dan Bimbingan Prodi Bimbingan Konseling Universitas Pendidikan Ganesha.

Nurhasanah, S, \& Sobandi, A. (2016). Minat Belajar sebagai Determinan Hasil Belajar Siswa. Jurnal Pendidikan Manajemen Perkantoran (JPManper), 1(1), 128-135.

Purwanto, A, Pramono, R, Asbari, M, Hyun, C. C, Wijayanti, L. M, \& Putri, R, S. (2020). Studi Eksploratif Dampak Pandemi COVID-19 terhadap Proses Pembelajaran Online di Sekolah Dasar. EduPsyCouns: Journal of Education, Psychology and Counseling, 2(1), 1-12.

Oemar Hamalik. 2011. Psikologi Belajar dan Mengajar, Bandung: Sinar Baru Algensindo.

Sardiman. 2014. Interaksi \& Motivasi Belajar Mengajar. Jakarta: Rajawali Press.

Setyorini, I. (2020). Pandemi COVID-19 dan Online Learning: Apakah Berpengaruh Terhadap Proses Pembelajaran pada Kurikulum 13? 
Journal of Industrial Engineering \& Management Research, 1(1), 95102.

Solihatin, E., \& Syahrial, Z. (2019). The Effects of Brain-Based Learning and Project-Based Learning Strategies on Student Group Mathematics Learning Outcomes Student Visual Learning Styles. Pedagogical Research, 4(4).

Sutarto et al. (2020). Teacher strategies in online learning to increase students' interest in learning during COVID-19 pandemic. Jurnal Konseling dan Pendidikan. Vol. 8, No.3, 2020, pp. 129-137.

Sugiyono. 2019. Metode Penelitian Kuantitatif, Kualitatif, dan R\&D. Bandung: Alfabeta.

Tim Kemenristekdikti. 2017. Buku Panduan; Pengisian Survei Pembelajaran dalam Jaringan, Jakarta: Kemenristekdikti.

Undang - Undang No 20 Tahun 2003 Tentang Sistem Pendidikan Nasional. 